\title{
The Rev. Griffiths Owen Corbett and the Red River Civil War of 1869-70
}

G.F.G. STANLEY AND W.L. MORTON have offered two contradictory and welldocumented interpretations of the first Riel resistance. Professor Stanley places the resistance within the framework of the frontier thesis. To him it was a 'manifestation ... of the problem of the frontier, namely the clash between primitive and civilized peoples. In all parts of the world, in South Africa, New Zealand and North America, the penetration of white settlement into territories inhabited by native peoples had led to friction and wars; Canadian expansion into the North-West led to a similar result. Here both half-breed population and Indian tribes rose in arms against Canadian intrusion and the imposition of an alien civilization.' ${ }^{1}$ Professor Morton disagrees with Stanley. For him 'what the Métis chiefly feared in 1869 was not the entrance of the agricultural frontier of Ontario into Red River - and they would have welcomed that of Quebec - but the sudden influx of immigrants of English speech and Protestant faith.' ${ }^{2}$

In both interpretations the Country-born (the English-speaking halfbreeds) and their clergy, all of the Church of England, are given minor but similar roles. Stanley places the Country-born solidly on the side of the Métis. They both resist the agricultural frontier together, as they must if his thesis is to be valid. Professor Morton is more reluctant to emphasize unity between the two groups but nevertheless comes to a similar conclusion: that 'the great central body of [Country-born] sentiment was inclined to risk nothing for Canada, and was at first not unsympathetic with the cause, if critical of the acts, of the Métis, with whom they possessed ties of blood and

1 G.F.G. Stanley, The Birth of Western Canada (Toronto 1936), vii

2 W.L. Morton, ed., Alexander Begg's Red River Journal and other Papers relative to the Red River Resistance of $1869-1870$ (Toronto 1956), 2 
of long association in hunt and trip.'3 Morton, then, considers the Countryborn ties of blood with the Métis more important than their ties of language and religion with the Canadians, in spite of the fact that his hypothesis would be considerably strengthened if the opposite were true.

New evidence, the 2 November to 4 December 1869 diary of the Rev. Joseph Phelps Gardiner, the Anglican incumbent of St Andrew's, the largest Country-born parish, indicates, however, that the Country-born and Métis were implacable enemies and that the Country-born were anxious to trounce the Métis at every possible opportunity. ${ }^{4}$ In fact, upon closer examination of the origins of Métis Country-born hatred, it becomes apparent that the first Riel resistance was in part caused and certainly exacerbated not by racial and religious antagonisms introduced by the Canadians, but rather by a sectarian and racial conflict with roots deep in Red River's past.

The Country-born and Métis were at odds years before the resistance, and the origins of that hatred lay in the nature of Red River society. The establishment of Red River by the Hudson's Bay Company had not been a thoughtless adventure with no consideration as to the nature of the society that was to be created at the forks of the Red and Assiniboine rivers. The retired gentlemen of the fur trade and, more importantly, the missionaries were to preach the gospel of civilization and Christianity and 'act it forth in life.' As members of the 'superior' order, whose position in society was divinely ordered, they, along with the gentlemen and the state, were to provide their 'inferiors' with leadership in all aspects of life. ${ }^{5}$ The Anglican clergy were recruited for the English-speaking Protestants and Catholic clergy for French-speaking Catholics.

One of the most important effects of the different teachings of the missionaries was to increase the religious dislike between the Métis and the Country-born. The Rev. David Jones, in Rupert's land from 1823 to 1833 ,

3 John E. Foster, 'The Country-born in the Red River Settlement' (unpublished PHD dissertation, University of Alberta, 1973), 4. Foster offers a definition of the term Country-born: 'Originating among the British-born residents of Red River, possibly as a polite affection, the term is not entirely satisfactory as its use suggests social class connotation. Apparently the term has particular reference to the mixed-blood children of British born officers.

Nevertheless, as the term defines a community distinct from the Métis, as it would have been recognized and understood by the community it designated, and as the term avoids the confusion in meaning and the perjorative sense associated with "Half-breed," "Countryborn" appears to be adequate to describe the second mixed-blood community in Red River. "Country-born" in short, signifies the English speaking mixed-bloods of the Red River Settlement.' Foster should, however, have added another modification. In Red River there were a few Catholics of English-speaking descent who tended to identify with the Métis rather than the Country-born community. The term Country-born then implies adherence to Protestantism. The Country-born were approximately equal in number to the Métis and resided in the parishes of St Paul and St Andrew's between Upper and Lower Fort Garry.

4 The diary is the Appendix of this paper.

5 Church Missionary Society Archives [CMSA], London, William Cockran to E. Bickersteth, 3 Aug. 1829 
caught one of his Country-born school boys berating a Catholic Métis for his church's practice of Latin preaching, image worship, and various other 'heathen' rites. The Catholic became so incensed that he ripped the catechism out of the Anglican's hands and threw it in the fire. ${ }^{6}$ William Cockran, a missionary in Red River from 1826 to $186_{5}$, found that the Catholic and Métis voyageurs despised him as a 'heretic, with a perfect hatred,' and that all of their actions were governed by the same 'bitterness of spirit.' They not only stole his provisions, they dropped his baggage in the water. ${ }^{7}$ Another painful issue was that of religious holidays, allowed by the Company to both Protestant and Catholic servants. The Catholics, it seemed to many a Protestant, had more than their share. Hostilities increased. ${ }^{8}$ The ties of Indian blood that united the Country-born and Métis could only have been weakened by these religious conflicts.

In the late 184 os the Country-born and Métis had considerable cause for joint action - a desire to destroy the fur monopoly of the Hudson's Bay Company so that all could join in the means for what appeared to be the good life. The cause was principally a Métis one, receiving considerable support from the Rev. Georges A. Belcourt, a secular cleric of the Church of Rome. It was observed by one who knew that 'Mr. B. est l'homme du peuple, on ne juge, on n'opéra que par lui. ${ }^{\text {'9 }}$ While James Sinclair, a member of the English-speaking community, was prominent in the movement, he considered himself Cuthbert Grant's successor as leader of the Métis, rather than a leader of his own people, the Country-born. ${ }^{10}$

The Country-born were reluctant to join the largely Catholic and Métis movement because it was condemned by the Anglican clergy as an evil 'Jesuitical plot' to increase the power of the Pope in Red River. The clergy had always emphasized and re-emphasized the positive nature of Protestantism and the evils of Catholicism. The anti-Company movement had all the appearance of being a Catholic work of the Devil. Any assistance to the Métis would place a Protestant's soul in mortal danger. ${ }^{11}$

The Country-born, then, viewing the Catholic Métis with a suspicious Protestant eye, sought to achieve acceptance by white British Red River. But this could not be. Because the Country-born were only half-white, they were considered to be seriously infected by the contagion of barbarism, and consequently forced to the periphery of society. Joseph Cook, a catechist for

6 Ibid., David Jones to the Secretary, 26 Dec. 1824

7 Ibid., William Cockran to the Secretary, 29 Aug. 1826

8 Hudson's Bay Company Archives [HBCA], London, B 235/a/5, f 63, Fort Garry Journal, 8 May 1823 ; f 16 d, 1 Nov. 1823

9 Archives de l'archevêché, Montréal, J.N. Provencher to I. Bourget, 23 juin 1849

10 Public Archives of Canada [PAC], Hargrave Papers, 3239, Donald Ross to James Hargrave, 29 April 1845

11 CMSA, W. Cockran to the Secretaries, 1 Aug. 1849; HBCA, D 5/25, ff $318-19$, Alexander Christie to George Simpson, 28 June 1849 
the Anglican Church Missionary Society, was upset, for example, at having been treated as only 'half an Englishman,' and expressed his discontent to the Society's secretary: 'I can assure you sir that we are rather beginning to get disgusted with our situation and treatment and the distinction which has been made between us and the European catechist and the too much lordship being exercised over us. ${ }^{12}$

The racial antagonisms came to a boiling point in 1850 with the Ballenden scandal. Dame Rumour, ably assisted by European Red River, had it that Mrs John Ballenden, the Country-born wife of the officer in charge of Upper Fort Garry, was an adultress. Desiring to clear Mrs Ballenden's name, her alleged lover Captain Foss brought charges of defamatory conspiracy against her detractors. What was important about the case was the fact that it split the settlement into white and Country-born fragments. It was 'a strife of blood - for even the Jurymen [who found for Mrs Ballenden] were all either Half-Breeds or married to Half-Breeds.' ${ }^{13}$ Antagonisms grew so bitter that neither faction spoke to the other. The wounds of this scandal lingered and never really healed. The Country-born realized that they were as unacceptable to European Red River as the Catholic Métis were to them. Raised as Protestants by religion and as Europeans by culture, their race prevented full acceptance into either European or Protestant Red River; the Countryborn could not turn to the Métis, his racial brother, and identify with this community, for the latter was an adherent of the hated Catholic faith.

The crisis of identity coincided with a crisis of population and politics. Growth in the later 185 os and early 186 os was phenomenal. In the six years preceding 1849 the population had increased by 148 ; in the following six years it increased by 1232 . The fisheries, the hunt, and the river lot could sustain such growth only with difficulty. ${ }^{14}$ Outwardly the most important problem of the 1860 s appeared to be the future of the settlement. As interest in Red River increased in the late $185^{\circ}$ os and early 1860 s by Great Britain as well as Canada, a struggle ensued in the settlement to hasten the end of Company rule and the coming either of Crown Colony government or annexation to Canada. The situation was all the more muddled because Red River was but vaguely aware of the discussions in the corridors of the Colonial Office and Beaver House. Confusion remained the only political certainty. ${ }^{15}$

The Rev. W.H. Taylor, an Anglican clergyman stationed in Red River, was

12 CMSA, Joseph Cook to the Secretaries, 29 July 1846

13 Archives of the Province of British Columbia, Victoria, Donald Ross Papers, Robert Clouston to Donald Ross, 17 Dec. 1850

14 Henry Youle Hind, Narrative of the Canadian Red River Exploring Expedition of $1857 \ldots$

(London 1860 ), I, 176-8

15 See F. Pannekoek, 'The Churches and the Social Structure in the Red River Area 1818-1870' (unpublished PHD thesis, Queen's University, 1973), Chap. vII 
acutely aware of the consequences of the malaise: 'There is an increase of those that drink ... and sad \& sickening of late have been the consequences of an excessive indulgence in whiskey. We mourn too over a recklessness of temper in some of the young of both sexes, - a disposition to spurn advise \& counsel - to set at naught ministerial and parental authority, and to follow the bent of their own sinful or vicious inclinations. Perhaps there is an increase of crime, \& as the papers report the cases brought before the Court - it may go abroad that we are a most immoral and iniquitous set of people. ${ }^{16}$ Because the faltering buffalo hunt was still for the most part successful, and because the Métis had a strong identity forged in the formative years of the settlement, they were able to cope with these pressures better than the Country-born. ${ }^{17}$

Since the most serious problems in Red River were those of the Countryborn, since the central problem was one of identity, and since the Countryborn had a tradition of religious leadership, it should be no surprise that a factious cleric should emerge to attempt to give direction to political, economic, and social discontent. The Rev. Griffiths Owen Corbett of the Church of England, and sponsored also by the Colonial and Continental Church Society, was a contentious and difficult individual, spending much of his life quarreling with his bishops, his sponsors, the Hudson's Bay Company, and his fellow clergymen. ${ }^{18}$ Corbett's agitation for political change began in $18_{5} 6$ and gained in momentum and acrimony to 1862 . Meetings were held throughout the settlement with increasing frequency and a number of petitions circulated advocating either annexation to Canada or Crown Colony status, with the latter appearing more certain until 1858. After that date union with Canada seemed more probable. Most of the Anglican clergy and the élite withdrew their support from the agitation in 1862 when the Company relieved the Rev. John Chapman, their chaplain and a cohort of Corbett's, of his position for unduly criticizing the Company. Corbett, along with James Ross, the Country-born son of Alexander Ross, the settlement's historian, continued to agitate. For his efforts Ross was deprived of his public offices of sheriff, governor of the gaol, and postmaster. ${ }^{19}$

When in early December 1862 Corbett was jailed for five times attempting to induce miscarriage by Maria Thomas, pregnant with his child, his protestations of innocence and accusations of a Company conspiracy were believed

16 Society for the Propagation of the Gospel Archives [sPGA], London, D 26, W.H. Taylor, Report, 13 July 1860

17 M. Giraud, Le Métis canadien (Paris 1945), 945-64. See also Archives Générales des Oblats de Marie Immaculée, Rome, Bishop Taché to the Superior General, 29 Nov. 1862

18 The Colonial and Continental Church Society Archives, London, General Minute Books, $1859-64$. See index for Corbett.

19 The Nor'Wester, Oct.-Dec. 1862 
by the Country-born. Many were convinced that Maria Thomas' father, a Country-born boatman who worked for the Company, was being forced to press charges by his employer. ${ }^{20}$ When Corbett was jailed, the Country-born demanded his immediate release and vindication. Throughout the episode the church refused to add its considerable weight to the Country-born cause and instead conducted a separate investigation, which too found Corbett guilty. ${ }^{21}$

The only alternative was for the Country-born to take the law into their own hands. On 21 April they forcibly released Corbett and two days later freed James Stewart, the school-master who had been imprisoned for his efforts in the Corbett jail break. The anti-Corbett faction was persecuted in every area of the settlement, especially in Corbett's parish, Headingley, and in the neighbouring parish of St James. Not only was the new incumbent of Headingley denied entrance to his church, but the Country-born refused to send their children to the church-sponsored school. ${ }^{22}$ Various clergymen were attacked for their views, especially Archdeacon James Hunter, who had conducted the clerical investigation into the Corbett case, and Bishop David Anderson. Hunter observed to the Secretaries of the Church Missionary Society that 'the storm is pitiless, a systematic blackening of the characters of all. No one can live in this land with this adversary, \& my prophecy is that in two years there will not be four clergymen on the two rivers. ${ }^{23}$ By 1867 all of the most prominent clergymen had left Red River: Bishop Anderson in 1864, James Hunter in $186_{5}$, and John Chapman and William Henry Taylor in 1867 . Their numbers were further reduced by William Cockran's death in $186_{5}$.

As Corbett crystallized the Protestant Anglo-Saxon identity of the Country-born he increased their hatred of the Catholics. He felt that the British liberties of Red River, a Protestant colony of a Protestant queen, were under attack and succumbing to the tyranny of the Pope. Corbett, seeing (as he imagined) too many examples of the growing power of the anti-Christ, felt it his duty to warn all of the dangerous consequences. His greatest concern was with William Mactavish's Catholic tendencies. Mactavish, the governor of Assiniboia, had married a Catholic in Saint-Boniface Cathedral, and in the following years baptized his children into the Catholic faith. ${ }^{24}$ All of Protestant Red River considered the marriage an insult to Bishop Ander-

20 The entire case is dealt with at length by J.J. Hargrave, Red River (Montreal 1871 )

21 CMSA, John Chapman to the Secretaries, 19 Feb. 1862

22 SPGA, D 41, W.H. Taylor, Report, 1 July 1863

23 CMSA, James Hunter to Henry Venn, 28 Jan. $186_{5}$

24 The Nor'Wester, 15 June 1861 . William Mactavish married a mixed-blood daughter of Andrew McDermot, a successful Irish Catholic English-speaking merchant. He was, because of his religion, one of the few who was able to maintain warm relations with both Métis and Country-born. On this ability rested his fortune. 
son, who had apparently expected to conduct the ceremony. Corbett was convinced that, with the governor a virtual Catholic, and with seven Catholics against seven Protestants on the Council of Assiniboia, 'the balance of power [was] with the Pope of Rome.'25

When an official report of the legislative proceedings of the Council of Assiniboia referred to the Catholic Bishop as 'Lord Bishop,' Corbett had what he considered proof of Popish ascendency. According to the priest, and legally he was correct, only Bishop Anderson, who wanted no part in the controversy and who unsuccessfully cautioned Corbett to moderation, was entitled to the honorific. Only he was appointed by 'Her Most Gracious Sovereign the Queen.' The use of the title for Bishop A.A. Taché was considered both 'insidious' and 'unconstitutional.' When during the dispute the Council of Assiniboia passed a law forbidding all government activity on Catholic holidays, there would no longer be any doubt for Corbett - Red River had fallen to the Pope. ${ }^{26}$

The degree to which the two communities had separated is apparent in the Stewart jailbreak referred to earlier. After Corbett had been released and Stewart incarcerated, the governor of Red River, suspecting a plot to free Stewart, called upon twenty-five Métis and twenty-five Country-born to defend the prison. Only five of the Country-born would serve; the Métis, who had no use for 'Corps bête' or his cause, appeared in full force. The Country-born mob defied the Métis guard and liberated Stewart. Fortunately most of the twenty-five Métis were from Saint-Boniface and under the control of moderates. Had 'les hivernants,' the Métis boatmen and tripmen living at Cheval Blanc and Saint-Norbert, been involved, as had been initially intended, blood would have been shed. They were hardly as charitable as their brethern at Saint-Boniface and, after the long confinement of winter, would have been ready to flex their muscles in the Red River spring air to teach the insolent Protestants a lesson. ${ }^{27}$

By 1863 , largely because of Corbett, the Country-born were certain of their identity. They were to liberate Red River from the two tyrannies of the Hudson's Bay Company and the Church of Rome and follow Corbett into a thoroughly Protestant and liberal British empire in which they, as Protestant Englishmen, would have the balance of power. ${ }^{28}$ Indifferent or hostile towards the Métis, the Country-born were ready, if indeed not eager, for the transfer to Canada that was formalized in 1870 . But because of the scandals of the 185 os and 60 , neither the church nor the fur trade gentry were

25 Ibid., 14 Dec. 1861

26 Ibid., 1, 15 April, 1, 24 May, 15 June, and 14 Dec. 1861

27 Archives de l'archevêché de Saint-Boniface, Winnipeg, 1313, Father Lestanc to Bishop

Taché, 21-23 April 1863

28 Annexation to Canada did not mean exclusion from the British empire or a Britannic identity. See Carl Berger, The Sense of Power (Toronto 1970). 
unified or influential enough to give direction to their wishes. The Country-born, lacking leaders of their own, looked eagerly after Corbett left in 1864 to dynamic Canadians like John Christian Schultz, a sometime doctor and more often storekeeper, for guidance. For the Country-born the Riel resistance was an obstacle to the political fulfilment of their new orientation formulated during the $186 \mathrm{os}$. They, unlike the Métis, did not have the need or the desire to protect their religion, language, or race.

Since the events of the resistance are well related by Professor W.L. Morton in his Introduction to Alexander Begg's Red River Journal, only the most important illustration of the argument that the Métis and Countryborn were at odds during the resistance and that the cause of this sectarian rivalry lay in Red River's past, not with the Canadians, will be examined in detail: the role of the Country-born in the December and February counterinsurrections intended to overthrow Riel. These events not only illustrate the bankruptcy of clerical and Country-born leadership but, more importantly, indicate that the Canadians were beginning to fill the gap. The resistance was, in fact, another step in the integration of the Country-born into the new Canadian-dominated Manitoba, a process which had commenced with the Corbett agitation. ${ }^{29}$

On 1 December, approximately two months after Louis Riel had stopped the surveys in Red River, formed a National Committee, and barred the highway at St Norbert, and one month after Riel had seized Lower Fort Garry, William McDougall, still at Pembina, declared himself governor, not knowing that the Canadian government had refused possession of the territory until Riel had been crushed. He despatched Colonel J.S. Dennis into the settlement as Conservator of the Peace with wide powers to put down the Métis insurgents. Dennis managed to raise a considerable force in the Country-born parishes of St Andrew's, St Paul's, and St John's. Largely because of Riel's timely seizure of the group of Canadians guarding Canadian government supplies in the small village of Winnipeg near Fort Garry, the English and Country-born show of strength collapsed.

With regard to Dennis's recruitments, Professor Morton is of the distinct opinion that the most eager and loyal to the Canadian cause were the Christian Indians of St Peter's parish, and that the English settlers, presumably he means the Country-born, 'responded slowly and in small numbers.' ${ }^{30}$ In fact they responded eagerly and were organized well before 1 December.

Indeed, by 25 November the Country-born had become so angry with Riel's seizure of the settlement's newspaper and the Company's cashbox, and

29 Some of the Country-born in anticipation, for example, joined Canadian organizations such as the Masonic Lodge in ${ }_{1864}$. William Douglas, Free Masonry in Manitoba ${ }_{1} 864-1925$ (Winnipeg 1925). The Lodge was started by Americans but was Canadian dominated. 3o Morton, ed., Begg's Red River Journal, 72 
his threat on the lives of some of the Anglican clergy, that James Ross, the chief Country-born spokesman, had little difficulty in arousing many in St Andrew's, the principal and oldest Country-born parish, to arm for a march on Upper Fort Garry to put down what they believed was the arbitrary dictatorship of Riel. At this point the Rev. Joseph Phelps Gardiner, the incumbent Anglican missionary at St Andrew's, interceded to counsel much-needed prudence. Feeling that the people were not sufficiently organized and that a conflict with the Métis would be disastrous, he urged that a Committee of Safety be formed and that the stock of arms and men be assessed. Two days later, on 27 November, the committee reported that while there were 302 men capable of bearing arms, there were only 203 guns and that many of these were old and useless. ${ }^{31}$

In spite of the absence of arms, the Country-born continued to press for action. In the first week of December J.S. Dennis reinforced Ross's appeal to arms and overrode Gardiner's hesitation by issuing his proclamation damning the rebels and by placing the St Peter's Indians in control of the Lower Fort and its substantial supply of gun powder. By 4 December there were eight forces in training: 71 at the Stone Fort, $5^{\circ}$ at St Andrew's, 36 at Portage la Prairie, 35 at St Pauls, 74 at Kildonan, 50 at St Peter's, 40 at Winnipeg, 31 at Poplar Point, and 31 at High Bluff. ${ }^{32}$ At least 400 were ready to march on Riel and many more would join if the movement showed any signs of success. But by 8 December the enthusiasm for armed action had subsided, probably because Riel had by then seized the Canadians guarding the government supplies in Winnipeg. James Ross, himself responsible for initiating the Country-born resistance, declared in a change of heart that 'a civil war is altogether too dear a price to pay for anything wanted on both sides. ${ }^{33}$ The circulation of Riel's November petition of right, outlining his aims, may also have allowed many to convince themselves that his intentions were ultimate union with Canada on honourable but negotiated terms. ${ }^{34}$

John Young Brown, a member of the Canadian Parliament and the brother of the last editor of The Nor'Wester, gave a more compelling reason for the failure of the counter-insurgents: 'A man of energy could he reach the settlement and organize the English and Protestant half-breeds would in a very short time restore authority. The chief danger arises from want of a head and the do nothing policy of the Red River Council. ${ }^{\prime 5}$ Red River had

31 See Appendix.

32 Great Britain, Parliament, Parliamentary Papers (House of Commons), 1870, I, Cmnd 10o9,

'Papers relating to the Red River Settlement, and Correspondence as to recent disturbances,' 393

33 Ibid., 398

34 Morton, ed., Begg's Red River Journal, 74-5

35 PAC, John A. Macdonald Papers, 40814-15, John Young Brown to John A. Macdonald, 18 Nov. 1869 
no such man of energy. Ever since the scandals of the 1850 and 6 os neither church nor fur-trade gentry were unified or influential enough to exert substantial influence over the Country-born. They did not attempt to do so in 1869 .

Also, despite the events of 1863 , the Country-born had not yet developed a strong leadership of their own. The likely organizer of a counterinsurrection was James Ross. Despite his University of Toronto education and sheriff-historian father, he was, however, hardly dynamic enough and much too vacillating - one moment he appeared to support Riel, the next the Canadians. Furthermore, he was a lapsed Anglican, now a Presbyterian, and therefore could never be anything but an intruder to the Country-born of St Andrew's. Still, he was the best Country-born Red River could muster and he did make their representations to the various conventions called by Riel. William Hallett, of whom little is known, might have been another possible candidate for the leadership of the Country-born cause. He had been in charge of their buffalo hunt, and therefore commanded prestige, but was lacking in the talent and power of personality necessary for co-ordinating any movement which included all the Country-born. Furthermore, as a guide for the Dennis survey party, he was under the influence of the Canadian party and looked to them for direction. He was also unstable, finally ending his life by suicide immediately after the collapse of the February attempt to put down Riel. Perhaps most unfortunate of all, many in Red River, especially some of the Kildonans and wealthier Country-born, considered him as nothing better than a common criminal. After all, he had been a chief conspirator in the Corbett jail-breaks. ${ }^{36}$

Up until 7 December ${ }_{1} 869$ the Anglican clergy, especially Bishop Robert Machray, were convinced that Riel must be stopped by force and did everything to ensure that he was, but they never went so far as to jeopardize seriously their facade of neutrality. The bishop probably heard as early as mid-September that the Métis were going to stop Governor McDougall at the border but thought the rumour so absurd that he did nothing. ${ }^{37}$ When Riel appeared before the 25 October meeting of the Council of Assiniboia at which Machray, a councillor, was present, and refused to change his views and allow McDougall entrance, the bishop was the only one to advocate active opposition. He suggested that a group of English- and Frenchspeaking mixed-bloods be sent to escort the governor to his residence at St James. The other more timorous councillors decided that two influential loyalist Métis should attempt to persuade Riel's supporters to disperse.

36 Queen's University Archives, Kingston, Charles Mair Papers, 'Murdoch McLeod,' 'J. Dilworth and Self,' and especially 'Notes on Early Rebellion,' contain some biographical material, but Hallett remains a shadow.

37 SPGA, Cyprian Pinkham, Annual Report, 4 Oct. 1869. If Pinkham was aware of a plot to stop McDougall it is inconceivable that Machray would not have known. 
Their plan failed. ${ }^{38}$ After Fort Garry was seized the bishop refused to advocate armed resistance publicly, although he most emphatically did so privately.

From November through to 7 December 1869 Machray surreptitiously pushed for a show of arms by the Country-born. On 21 November 1869 during the first Convention, called by Riel to decide on the terms for negotiation, a number of clergymen met with John Schultz and James Ross. What transpired or who attended is not known, but a few days later, as noted earlier, James Ross was preaching insurrection against Riel at the St Andrew's school house. ${ }^{39}$ It is not improbable that he was encouraged to do so by the clergy. On 4 December, three days after J.S. Dennis had published his appeal for assistance to put down Riel, Bishop Machray, at a missionary meeting at St John's with most of his clergy present, proclaimed Protestantism in danger and again urged armed resistance. ${ }^{40} \mathrm{~B}$ ut he did so privately to his clergy. To Riel he wanted to appear scrupulously neutral. If resistance failed he could blame and admonish his clergy. On 6 December, for example, Bishop Machray showed reluctance to urge Schultz to disperse his men surrounding the Canadian government's winter supplies in Winnipeg. ${ }^{41} \mathrm{He}$ believed that if they fell into the hands of the Métis the resistance would be prolonged. But so fearful was Machray of upsetting Riel that he asked for the latter's advice on the matter. Riel, aware of Machray's duplicity, replied that the bishop was too good a man to speak to Schultz. Only on the evening of 7 December, after the attempt at resistance on the part of the lower parishes had collapsed and all hope of successful counter-insurrection was dashed, did Machray finally come out in favour of the laying down of arms by the men in Schultz's house. ${ }^{42}$ After this date Bishop Machray refused to countenance any action publicly or privately that might involve violence. He would wait for imperial troops.

Only three times after 7 December did Machray become involved in the Riel troubles: during the proceedings of the January-February convention, during the ${ }_{14}$ February insurrection, and during the execution of Scott. ${ }^{43}$ On all three occasions he urged moderation and showed apparent support for the provisional government. He refused to allow his own election to the conventions or as a delegate to treat with Canada for fear of incurring the displeasure of the Catholic clergy. ${ }^{44} \mathrm{He}$ continually urged the Englishspeaking half of Red River to remain quiet and was untiring in calming the

$3^{8}$ E.H. Oliver, ed., The Canadian North-West: Its Early Development and Legislative Records

(Ottawa 1915), 618

39 Morton, ed., Begg's Red River Journal, 176

40 Appendix

41 Morton, ed., Begg's Red River Journal, 211

42 Ibid., 220

43 Ibid., 276

44 Ibid, 282 
attempted counter-insurrection. His rule was that 'there is but one sensible course in the peculiar circumstances of this country, which is to give in if at all practical. ${ }^{15}$ But his continued anti-Riel sentiments were definite. ${ }^{46}$ As late as April 1870 , when matters in Red River had become more settled, he was still of the opinion that "things remain in a very sad condition. I doubt whether England ever in her history has allowed things to go as they have done here for the past 6 months. - If she does not act in some way to ensure protection and order for her Loyal subjects what is the meaning of the claim of Empire.' ${ }^{47}$

Machray's clergy followed his policy. At Portage la Prairie the Rev. Henry George expressed neutrality but openly consorted with the Canadian party, while Archdeacon John McLean of St John's parish followed precisely in Machray's footsteps - visible neutrality towards but private damnation of Riel. ${ }^{48}$ John Phelps Gardiner, the incumbent of the most prosperous and populated Country-born parish, St Andrew's, and the only clergyman arriving after $186_{5}$ who appears to have developed close ties with the Countryborn, was in the best position to influence the course of events. Gardiner, however, abdicated his position early during the course of events. While on 21 October he was instrumental in drawing up an address of loyalty to the crown and of welcome to McDougall, and appeared ready to resist Riel, by early November he refused to interfere. The reason was the threat made on his life on 5 November by the Métis, who feared Gardiner's influence and his anti-Catholicism. ${ }^{49}$

Only the Canadian party, then, could offer Country-born Red River the direction it wanted. Like the Canadians, the Country-born had no love for the Catholicism of the Métis, and wanted either Crown Colony status or annexation to Canada. Because of the new identity forged in the Corbett crisis, the Country-born did not fear the Canadian surveyors and Canadian land speculators as did the Métis. ${ }^{50}$ There was no deep-rooted hatred of Dr John Schultz and the Canadian party. If any questioned the Canadian's

45 CMSA, Bishop Machray to the Secretary, 1 March 1870

46 See, for example, Morton, ed., Begg's Red River Journal, Bishop Machray to John Young, 18 March $1870,502-10$

47 SPGA, Bishop Machray to the Secretary, 16 April 1870

$4^{8}$ Ibid., Bishop Machray to Secretary Bullock, 21 June 1870; Cyprian Pinkham, Annual Reports, 25 June 1870,4 Oct. 1869 , and Jan. 1870

49 Appendix

5o Stanley, Birth of Western Canada, 62, maintains that Thomas Bunn, a prominent Countryborn, stated that if the surveyor's had crossed the land of the English half-breeds instead of that of the Métis, they too would have resisted. His evidence is Thomas Bunn's deposition printed in Canada, Parliament, Journals (House of Commons), 1874 , Report of the Select Committee on the Causes of the Difficulties in the North-West Territories in $1869-70$, Appendix No 6,115. Stanley has taken this evidence out of context. The same deposition maintains that only 'a small portion of the English-speaking population' were opposed to the 
over-zealous activities in favour of union, it was probably the old retired gentlemen and their wealthier offspring, who could not only have felt the attacks by the Canadians on the Company through their press, The Nor'Wester, unjustified, but would also have feared that the Canadians would occupy a more prominent place than they in the social structure of the new West. ${ }^{51}$ Equally important, the Country-born would not necessarily have listened to the urgings for caution by their clergy. They had been abandoned by the church in the Corbett crisis, and would move without its approbation.

After the 7 December decision by the Anglican bishop to espouse publicly a pro-Riel neutrality, the Canadians seized the first opportunity to assume the leadership of the willing Country-born. ${ }^{52}$ It came in February 1870. Both Charles Mair and John C. Schultz had been jailed in December by Riel after he had seized the government supplies in Schultz's custody. On 9 January Mair escaped to Portage la Prairie where he resided with John Garrioch, a prominent Country-born, and the Rev. Henry George; Schultz, breaking jail on 23 January, fled to the lower Country-born parishes of St Paul's and St Andrew's. Throughout January Mair held and encouraged secret meetings at the homes of both Canadian and Country-born settlers in Portage and the neighbouring community of High Bluff in an effort to raise a force to release the remaining and supposedly greatly suffering prisoners at Fort Garry. Captain C.A. Boulton of the Canadian survey party, initially reluctant to approve action, partly because Colonel Dennis had commanded him to keep Portage quiet, was in the end persuaded by Mair to assume command. On 10 February sixty men left Portage for Headingley where, because of a blizzard, they were confined to the church and, it might be conjectured, the willing care of the Rev. J. Carrie. Four days later the forces, swollen by recruits from the English-speaking parishes along the Assiniboine, met Schultz at St Paul's and from there marched to Kildonan. Succeeding where Ross had failed in December, Schultz had spent the weeks since his escape encouraging and organizing the lower parishes, especially St Peter's and St Andrew's, in their plan for resistance. On the morning of 14 February, then, some 500 men, mostly semi-armed Country-born, were ready to take up a position at Saint-Boniface Cathedral and with the single

surveys. Furthermore, Bunn observes that 'the French Métis claimed for all the half-breeds a right to the lands of the country generally; but the English half-breeds did not [my emphasis] put forth that claim.' He further recognized the English half-breed reluctance to join the Métis and blames this on the Anglican clergy. Perhaps Thomas Bunn could have been an influential leader of the Country-born during the resistance but he was, as he himself recognized, too sympathetic to the rebel cause. His following was insignificant.

51 It must be emphasized here again that because of the Ballenden affair and the Corbett scandal the Country-born élite did not for the most part hold the respect of the Countryborn generality. See Pannekoek, 'The Churches and the Social Structure,' $25^{0-2}$.

52 CMSA, Bishop Machray to Secretary Venn, 1 March, 1870 
cannon Schultz had brought down from the Lower Fort, breach the walls of Fort Garry. ${ }^{53}$ But the force never left Kildonan. Instead it was Riel who secured the position at Saint-Boniface.

Canadian leadership proved ineffective. Schultz, physically a very impressive figure, assumed the leadership of the Country-born and the St Peter's Indians but, for no apparent reason, he was reluctant to assume direction of the entire February movement once it arrived at Kildonan. ${ }^{54}$ With Schultz hesitating and the clergy chattering for peace, the Country-born dispersed in frustration. There is no doubt that had Schultz chosen to lead the Protestant parishes, he could have appealed to their sectarian and imperial predilections with considerable success, for many were convinced that the rebellions were 'a flame the Jesuits have kindled to exterminate Protestantism..$^{55}$

If the Canadians and the Protestant clergy were not willing to lead a military insurrection, they nevertheless made the best of the situation. The Rev. John Black, a Canadian Presbyterian, presumably with the backing of the Anglican clergy and the Canadians, sent a letter to Riel withdrawing the Protestant delegates from the convention. While perhaps the move was an effort to appease the Country-born, who had already censured their delegates for supporting Riel, and to prevent armed conflict, another equally probable argument is that the move was intended to pull success out of a faltering military expedition. After Riel had seized and planted arms at Saint-Boniface, the strategic position for the bombardment of Fort Garry, even Schultz must have realized that attack was futile. With the withdrawal of the delegates, Riel could no longer pretend to control Red River or to speak for its inhabitants. Canada would then be compelled to send out troops to restore order. It was a clever move and totally in character with the pro-Union sentiments of the Canadians, the clergy, and the Country-born. ${ }^{56}$ The scheme, however, failed. A number of would-be insurgents were captured by Riel on their way back to Portage la Prairie. By threatening the execution of Major Boulton, he forced the Country-born to re-elect delegates to the provisional government. So the facade of unity between Country-born and Métis was maintained.

The dismal failure of both the December and February uprisings indicates the transitional state of the Country-born and its leadership. The Country-

53 There are several accounts of the uprising. The best secondary account is by Norman Shrive, Charles Mair, Literary Nationalist (Toronto 1965), 99-107. The best primary account is by Charles A. Boulton, Reminiscences of the North-West Rebellions (Toronto 1886). See also Queen's University Archives, Charles Mair Papers, manuscripts entitled 'Murdoch McLeod,' 'J. Dilworth and Self,' and 'Notes on Early Rebellion.'

54 Morton, ed., Begg's Red River Journal, 312

55 Ibid., 494-7

56 Ibid., $310-12$ 
born, largely as a result of the energies of the Rev. G.O. Corbett, had redirected their identity and goals in the 1860 s. From parochial settlers whose concern was principally with the internal politics of Red River, their energies were now with the empire and Protestantism. In the process of social change the church had increasingly alienated the Country-born. The December insurrection illustrated the inability of the church as well as the Country-born élite to assume responsibility for leading Red River. By February the Canadians had assumed the initiative, but their indecisiveness and the poor military position of the Country-born had prevented action.

The Red River resistance has been viewed as either a frontier problem or as the transfer of Canadian sectarian problems to the West. While neither of the interpretations is without considerable validity, this brief examination indicates that perhaps a new approach is possible. What must be emphasized is Red River's particularity, and the fact that it had a unique historical impetus. Many of the tensions evident during the resistance, especially between the Country-born and the Métis, were the result of racial and religious tensions dating back to the 183 os and culminating in 1863 . The Riel resistance was then an anti-climax at least for the Country-born. They had transferred their allegiance and sympathies to Canada and the Canadians by 1863 .

APPENDIX

\section{J.P. Gardiner's Diary for the Riel Resistance}

November 2 Tuesday.

Went to Fory Garry. While there the Rebels came \& took possession of the Fort.

Before going to the Fort I head they were $\operatorname{com}^{\mathrm{g}}$ to burn $\mathrm{D}^{\mathrm{r}}$ Schultz's [sic] house - I was mention ${ }^{\mathrm{g}}$ this to $\mathrm{D}^{\mathrm{r}}$ Cowan at the Fort but he laughed at the idea. While talk ${ }^{\mathrm{g}}$ to him we saw $a b^{t} 100$ of them with their guns $\operatorname{com}^{\mathrm{g}}$ toward the fort. They marched in three abreast \& when the Chief (Mr Riel) had placed sentries at each gate he asked for Gov ${ }^{\mathrm{r}}$ McTavish.

[November] 5. Friday.

Ann Meet ${ }^{g}$ of the Young Men's Xtn Ass. Bp \& both Archdeacons present Mr Ross and Dr Bedd [ine] full meet ${ }^{\mathrm{g}}$. Archdeacon McLean took me aside soon after he arrived \& told me that a R.C. had threatened to take my life. He said 'You remember what they said $\mathrm{ab}^{\mathrm{t}}$ your sermon at the opg [opening] of Trinity ch \& on one or two occasions you have spoken out very plainly $\mathrm{ab}^{\mathrm{t}}$ the $\mathrm{Ch}$ of Rome. but do be careful-for I fear they mean to do y mischief. One of them said that you $s^{d}$ be the first to be strung up.' It was not pleasant information but God reigneth \& they cannot take my life till he permits. I shall however take every precaution \& not go out except well armed. 
What a sad business this Insurrection is. It will spoil every good work this winter.

[November] 7 Sunday.

Since Friday I have felt very anxious. It is not a pleasant thought to feel that any time one may be shot, or taken prisoner \& put to death by a R C mob. There is consolation in Xt \& I took to Him for grace to enable me to go $\mathrm{bb}^{\mathrm{t}}$ my work as usual \& to be more \& more prep ${ }^{d}$ every day if I am taken but my dear wife \& children! Texts today Luke 24.32 as [Acts?] 2.12

[November] 8 Monday.

Spoke to the $\mathrm{Bp} \mathrm{f}$ advice in ref to the threat $\mathrm{ag}^{\mathrm{st}}$ my life \& also to ask if $\mathrm{Mr} \mathrm{R}$ McDonald student in The College might not be sent to take the sch at Little Britain.

[November] 13. [Saturday]

The Insurgents have issued a paper calling on the English speak ${ }^{\mathbb{g}}$ people to send Delegates to confer with them upon the state of the Country. A meet ${ }^{\mathbb{E}}$ was held in the Sch room here today to elect one. I did not attend the meet $t^{\mathrm{g}}$ think $^{\mathrm{g}}$ it best to keep as clear of the matter as possible. Mr Gunn was elected to represent this Parish.

[November 14 Sunday.]

The Sunday Scips Heb VI.1 8. 1 John 1.7 Rev 7.17

[November] 20 Saturday.

This has been a most anxious week. Delegates returned home Yesterday \& have to return to another Conference Monday.

[November] 25 Thursday

Since my last entry I have been a good deal employed in getting people to protest $\mathrm{ab}^{\mathrm{t}}$ Liquor Licences - there are 4 applications in the Parish I have succeeded in stopp $\mathrm{p}^{\mathrm{g}}$ $3 \&$ Mr Gunn has promised to see to the other. There was a meet ${ }^{\mathrm{g}}$ today of the Parish to hear Mr Gunn's report of the Conference with the French people. I did not intend to go so went down to Mr. Cowleys - found that he was at Mapleton to attend a similar meeting in his parish.

On reaching home late in the afternoon I found the meet ${ }^{\mathrm{g}}$ still going on - I went in. Mr. Jas Ross was speak ${ }^{\mathrm{g}} \&$ ask $^{\mathrm{d}}$ the people to go \& take away some Gov ${ }^{\mathrm{t}}$ provisions $\mathrm{w}^{\mathrm{h}}$ the Insurgents have seized - asks them if they were will ${ }^{\mathrm{g}}$ to go at [?] the point of the Bayonet - I was shocked at some things he said \& left the room - after a while I went in $\mathrm{ag}^{\mathrm{n}}$. I found that they had passed resolutions to go and take the Fort \& 40 sledges \& $a b^{t} 100$ escort were pledged to go. I protested $a b^{t}$ this. This people I know are not prepared for this \& suggested that they $\mathrm{sh}^{\mathrm{d}}$ form a Comm of Safety for self defence ascertain how many men we have \& how many guns \& as the French have proposed a Provisional Gov ${ }^{t} \&$ the people protested agst this. It was resolved to obtain the signatures of all the English people agst it. Our people are not organized \& a conflict with the French $w^{\mathrm{d}}$ be most disastrous. 
[November] 27 Saturday.

The Com for Public Safety reported 302 men in the Paris \& 203 guns \& some of these guns very bad ones. A Comp ${ }^{y}$ of volunteers are to be enrolled \& the men are to drill every wk.

Dec. 4 Saturday.

Went to Bp's Court to attend a Com Mett ${ }^{\mathrm{g}}$. For an hour \& half we talked over the state of the Settlement. The Bp thinks it has come to this that every man must take a decided stand for loyalty \& religion \& act for his own people's safety. It was remarked by Archdeacon Cowley that the c.M.s. laid it upon all its Missys not to mix up with any political movement. The Bp replied that C.M.s. rule did not apply to this for every Protestant was in danger \& nothing was to be done his Lordship thought but fight or submit. 